\title{
Cat scratch disease: The story continues
}

\author{
MARY ANNE OPAVSKY MSc MD FRCPC
}

MA OPAVSKY. Cat scratch disease: The story continues. Can J Infect Dis 1997;8(1):43-49.

OBJECTIVE: To present a perspective on the current state of knowledge of cat scratch disease (CSD), including the evidence for Bartonella henselae as the etiological agent, epidemiological and clinical characteristics of the disease, available diagnostic tests and current therapeutic options.

DATA SOURCES: MEDLINE search of the literature published from 1966 to 1995 using 'cat scratch disease', 'Bartonella henselae', 'Rochalimaea henselae' as key words and bibliographies of selected papers.

DATA EXTRACTION: Selected studies reporting data on etiology, epidemiology, clinical characteristics, diagnosis and therapy of CSD were evaluated.

DATA SYNTHESIS AND CONCLUSIONS: Evidence accumulated to date supports $B$ henselae as the etiological agent of CSD. The most significant risk factors for CSD are being licked on the face, scratched or bitten by a kitten and owning a kitten with fleas. Available serological tests can confirm classic CSD and identify $B$ henselae as the cause of more atypical presentations, such as fever of unknown origin, granulomatous hepatitis, encephalitis and osteomyelitis. Symptomatic management is appropriate for isolated lymphadenopathy caused by CSD in healthy individuals; however, antibiotic therapy may be indicated for patients with more severe manifestations of the disease and immunocompromised hosts. Further study of CSD, in particular the epidemiology and therapy, is warranted. A better understanding of the pathogenesis of $B$ henselae infection will have important implications in both immunocompetent and immunocompromised individuals.

Key Words: Bartonella henselae, Cat scratch disease, Rochalimaea henselae, Serological testing

\begin{abstract}
Maladie des griffes du chat : I'histoire se poursuit
OBJECTIF : Présenter l'état actuel des connaissances sur la maladie des griffes du chat, y compris les preuves confirmant le rôle étiologique de Bartonella hensela, les caractéristiques épidémiologiques et cliniques de la maladie, les épreuves diagnostiques disponibles et les options thérapeutiques actuelles.

SOURCES DES DONNÉES : Interrogation du réseau MEDLINE pour la littérature publiée entre 1968 et 1995 à partir des termes clés "cat scratch disease», Bartonella henselo, Rochalimaea hensela, et consultation des bibliographies d'articles sélectionnés.

EXTRACTION DES DONNÉES : Les études sélectionnées faisaient état de données sur l'étiologie, l'épidémiologie, les caractéristiques cliniques, le diagnostic et le traitement de la maladie des griffes du chat.

SYNTHÈSE DES DONNÉES ET CONCLUSIONS : Les preuves accumulées à ce jour tendent à incriminer $B$. henselae comme agent étiologique de la maladie des griffes du chat. Les facteurs de risque les plus significatifs de la maladie sont : le léchage du visage, les égratignures ou morsures infligées par un chaton et l'infestation des chatons par des puces. Les épreuves sérologiques disponibles peuvent confirmer la maladie des griffes du chat classique et permettre l'identification de $B$. henselae comme cause de tableaux plus atypiques, comme la fièvre d'origine inconnue, l'hépatite granulomateuse, l'encéphalite et l'ostéomyélite. Le traitement des symptômes est approprié dans les cas de lymphadénopathie isolée causée par la maladie des griffes du chat chez des sujets par ailleurs en santé. L'antibiothérapie s'impose toutefois chez les patients plus gravement atteints et chez les hôtes immunodéprimés. D'autres études sont nécessaires pour mieux comprendre l'épidémiologie et le traitement de la maladie des griffes du chat. Une meilleure compréhension de la pathogenèse de l'infection à $B$. henselae aura d'importantes répercussions tant chez le sujet immunocompétent que chez le sujet immunodéprimé.
\end{abstract}

Winner of the Canadian Infectious Disease Society/Canadian Journal of Infectious Diseases Review Article Award; portions of this review have also been submitted as part of a Canadian Paediatric Society statement on cat scratch disease

The Hospital for Sick Children, Toronto, Ontario

Correspondence and reprints: Dr MA Opavsky, Division of Infectious Disease, The Hospital for Sick Children, 555 University Avenue, Toronto, Ontario M5G 1X8. Telephone 416-813-6273, fax 416-813-5032 
$\mathrm{R}$ ecently, Bartonella henselae has been identified as the causative agent of cat scratch disease (CSD). Parinaud first described conjunctival inflammation with preauricular adenopathy following animal contact more than 100 years ago. In 1931 Debré observed the occurrence of regional lymphadenopathy following cat scratches, then 20 years later published a report of "la maladie des griffe du chat", establishing CSD as a clinical entity (1-3). Serological testing for this organism in humans and their cats, as well as the culture of $B$ henselae and the detection of $B$ henselae DNA from lymph nodes in patients with clinical disease, supports the role of this organism in CSD (4-7). Formerly known as Rochalimaea henselae, the organism was reclassified as $B$ henselae in 1993, following 16S rRNA sequence analysis (8). Based on the high degree of relatedness with Bartonella bacilliformis, all Rochalimaea were reclassified into the genus Bartonella. Diseases caused by the other four species in the genus, Bartonella quintana, B bacilliformis, Bartonella elizabethae and Bartonella vinsonii, share epidemiological, clinical and histopathological characteristics with $B$ henselae.

The identification of the bacteriological cause of CSD and the development of new diagnostic tests have broadened the spectrum of disease associated with $B$ henselae infection. Thus, this is an opportune time to review CSD, available tests and management issues.

\section{THE AGENT OF CSD}

In 1983 Wear et al (9) first identified a small Gram-negative organism in the lymph nodes of patients with CSD. Following this breakthrough English et al (10) reported successful culture of an organism from lymph nodes of patients with CSD. The organism, later designated as Afipia felis, also became accepted as the agent of bacillary angiomatosis (BA), a syndrome originally identified in patients infected with human immunodeficiency virus (HIV) $(11,12)$.

Using 16S RNA molecular technology Relman et al (13) amplified a bacterial gene fragment from BA lesions. This amplification product most closely resembled the genome of $B$ quintana, the cause of trench fever (13). Independently, also in 1990, Slater et al (14) isolated a fastidious Gram-negative organism from febrile immunocompetent and immunocompromised patients. Eight of nine organisms were identical to $B$ henselae, the organism described by Relman et al (13).

A wealth of evidence supporting $B$ henselae as the etiological agent of CSD has accumulated. With the development of an indirect fluorescent antibody (IFA) assay for $B$ henselae, Regnery et al (4) demonstrated increased titres in patients with clinically diagnosed disease. Elevated titres to $B$ henselae were also found in the cats of CSD patients (15). Using polymerase chain reaction (PCR) methods, DNA amplified from CSD skin test antigen preparations was identified as $B$ henselae, and not $A$ felis $(16,17)$. Although isolated from blood in febrile immunocompetent and immunocompromised patients earlier, $B$ henselae was directly linked with CSD when the organism was grown from lymph node tissue of patients with classic CSD $(5,14,18)$.

Bacteremia with $B$ henselae has been demonstrated in bar- tonella-seropositive cats $(19,20)$. Cats with asymptomatic $B$ henselae infection can remain bacteremic for several months, possibly acting as a reservoir of the infection (20). Seropositive animals were not protected from bacteremia.

Although reports supporting $A$ felis as an cause of CSD or suggesting a dual role for $B$ henselae and $A$ felis continue, overwhelming evidence supports $B$ henselae as the major cause of CSD $(21,22)$.

\section{EPIDEMIOLOGY OF CSD}

An estimated 22,000 cases of CSD, with more than 2000 hospital admissions, are diagnosed every year in the United States, peaking in fall and winter (23). The incidence is between 1.8 and 9.3 cases per 100,000 population $(15,23)$. In a comprehensive analysis of epidemiological and clinical characteristics of CSD, Carithers (24) found $87 \%$ of patients with the disease were 18 years of age or younger (24). The age distribution may in fact be broader, and CSD may not be primarily a disease of children, with $43 \%$ of patients in a recent survey being 21 years of age or older (25).

The association between cats and human infection with $B$ henselae was confirmed following the identification of the bacteriological cause of CSD. More than $90 \%$ of patients have a history of cat contact. In a case control evaluation, CSD occurrence was most strongly associated with owning a kitten (12 months old or younger), being licked on the face, scratched or bitten by a kitten, or owning a kitten with fleas (15). Serology for $B$ henselae was positive in $84 \%$ of CSD patients compared with $3.6 \%$ of controls (15).

In an assessment of patients with CSD, $68 \%$ of their kittens had positive blood cultures for $B$ henselae, and all kittens had fleas (26). One kitten had fleas positive for $B$ henselae DNA by PCR, further implicating fleas in disease transmission.

A North American seroprevalence study of bartonella antibodies in cats revealed the highest average prevalence in warm, humid areas, which are also areas with the highest number of potential arthropod vectors. The percentage of seropositive cats ranged from 0\% in Calgary and Edmonton, Alberta, $47 \%$ on Vancouver Island, British Columbia, and to a high of $71 \%$ in Memphis, Tennessee (27).

\section{CLINICAL PRESENTATION WITH CSD}

Typical CSD presents with a 3 to $5 \mathrm{~mm}$ papule at the site of inoculation three to 10 days after animal contact $(2,24)$. The lesion, initially a macule, can progress to a papule, pustule or vesicle. Careful search for inoculation papules, which can be seen in $60 \%$ to $93 \%$ of cases, can provide support for the diagnosis $(24,28)$. Regional lymphadenopathy proximal to the site of inoculation is observed seven to 60 days later. In one-half of patients lymphadenopathy is an isolated finding, involving the head, neck or upper extremities in most cases. Initial tenderness has been described in $80 \%$, and while $12 \%$ to $15 \%$ become suppurative, cellulitis is rare. Resolution occurs spontaneously within two to four months $(2,24)$. Up to $30 \%$ of patients experience associated fever and malaise, with anorexia observed in $15 \%$; however, these systemic symptoms may reflect unidentified systemic disease (2). 
While the majority of patients with CSD present with regional lymphadenopathy as described above, atypical presentations have been observed in $5 \%$ to $14 \%$ of patients $(2,29)$. Parinaud's oculoglandular syndrome, with preauricular lymphadenopathy and conjunctivitis, is the most frequent, occurring in $6 \%$ of patients (2).

Systemic CSD with hepatosplenic involvement is being noted more frequently (29-32). Typically in the course of investigating a fever of unknown origin $(32,33)$ or a suspected malignancy (34), scattered hypoechoic lesions on ultrasound or hypodense lesions in the liver and/or spleen are found on computed tomography scan. The lesions appear to be abscesses, and on histological examination necrotizing granuloma are revealed. Patients are generally systemically unwell with prolonged fever, malaise and weight loss (35). Lymphadenopathy is seen in approximately one-half of cases. Periportal or periaortic adenopathy can occur. Hepatosplenic involvement is not consistently associated with organ enlargement, and liver function tests are usually normal. Evidence of visceral granuloma usually disappears within one to five months, but lesions can become calcified (36). Recurrent febrile episodes may occur without known reinoculation (37).

Central nervous system involvement typically occurs two to six weeks after the onset of lymphadenopathy, presenting with seizures, headache or encephalopathy (38-41). Neurological symptoms have been noted in $1 \%$ to $7 \%$ of CSD cases $(15,24)$. No major sequelae have been identified. Cerebral spinal fluid analysis can be normal, or indices can be consistent with a viral process $(38,39)$. Transient cranial nerve dysfunction and myelopathies are also associated with CSD (38).

Neuroretinitis, alone or with Parinaud's oculoglandular syndrome, has presented with reversible acute unilateral loss of visual acuity or blindness $(39,42-44)$. Retinal edema, optic disc swelling and/or a macular star can been seen on fundoscopy.

Pulmonary involvement, with pneumonia and/or pleural effusion, has also occurred with CSD. Lymphadenopathy was apparent in all cases, and the majority of patients had multisystem involvement (45). Investigation of pulmonary nodules in an immunocompromised renal transplant patient identified $B$ henselae as the pathogen, and the organism was isolated from eight of the patient's cats (46).

Bone involvement, in the form of clinical osteomyelitis with lytic lesions on x-ray and $B$ henselae identified by culture or pathology of the lesions, can present with systemic disease (47-49). Bone lesions may be adjacent to overlying adenopathy. Osteolytic lesions can present with localized pain without erythema, tenderness or swelling $(50,51)$.

Skin manifestations have been described in $5 \%$ of patients with CSD, most commonly maculopapular rashes early in the disease. In addition, vesicular eruptions, erythema nodosum, erythema multiforme, urticaria, purpura and leukocytoclastic vasculitis have been described (52-54). Hematological abnormalities observed include thrombocytopenic purpura and hemolytic anemia $(2,55)$.

Classic and atypical CSD have been reported in patients
TABLE 1

Spectrum of clinical presentation of cat scratch disease

\begin{tabular}{lc}
\hline Presentation & Reference \\
\hline Regional lymphadenopathy & 5,83 \\
Systemic disease, ie, fever, malaise, & 35 \\
$\quad$ weight loss, myalgia & \\
Fever of unknown origin & 32,33 \\
Suspected malignancy & 34,51 \\
Hepatosplenic granulomatous lesions & $29-32,36$ \\
Parinaud's oculoglandular syndrome & 2 \\
Encephalitis, encephalopathy, myelitis & $38-41$ \\
Neuroretinitis & $42-44$ \\
Osteomyelitis & $47-51$ \\
Pneumonia and/or pleural effusion & 45,81 \\
Skin rashes & $15,52-54$ \\
Nonimmune hemolytic anemia, & 2,55 \\
thrombocytopenic purpura & \\
\hline
\end{tabular}

with HIV infection or following organ transplantation $(42,46,56) . B$ henselae infection should be considered if any manifestations of CSD are present in immunocompromised individuals $(46,56)$.

The clinical spectrum of CSD is summarized in Table 1. With continuing reports of cat/kitten-related illnesses the range of disease will only increase. The widespread use of available serological testing will provide additional information regarding the prevalence of clinical signs and symptoms of CSD and their relationship to both typical and atypical disease.

\section{OTHER BARTONELLA INFECTIONS}

$B$ henselae is closely related phylogenetically to $B$ quintana, $B$ bacilliformis, $B$ elizabethae and $B$ vinsonii (8). Some interesting epidemiological and clinical similarities exist among these species.

Evidence supports a role for both $B$ henselae and $B$ quintana in the pathogenesis of BA and bacillary peliosis (BP) (57-59). BA, first described in HIV-infected patients, presents with lesions different from those associated with CSD. Most commonly cutaneous or subcutaneous lesions characterized by vascular proliferation and the presence of bacillary organisms are seen $(12,57)$. Patients with extracutaneous disease, including bone, lung and brain involvement, usually have accompanying systemic symptoms. BP is associated with comparable vascular lesions in the liver and spleen $(57,60)$. Traumatic cat contact has been associated with the development of $\mathrm{BA}$ and $\mathrm{BP}$ in immunocompetent and HIV-infected individuals $(57,61)$.

Historically $B$ quintana, the etiological agent of the louseborne disease trench fever, and $B$ bacilliformis, the cause of bartonellosis, have been responsible for significant human disease (28). Both Oroya fever and the cutaneous phase of the disease, verruga peruana, are manifestations of bartonellosis and are spread by a sandfly vector that transmits $B$ bacilliformis (28). A role for fleas in CSD and in other $B$ henselae infections is particularly attractive, given the involvement of 
the arthropod vectors, the sandfly and the louse, in the transmission of Oroya fever and trench fever, respectively.

Similarities between the lesions of BA and BP and of verruga peruana due to $B$ bacilliformis have been noted because they cause an angioproliferative host response $(57,58,62)$. While molecular and histological investigations have proven these infections distinct, common mechanisms of pathogenesis may ultimately be found (28).

Prolonged fever with no evidence of focal infection can occur with persistent $B$ henselae or $B$ quintana bacteremia in immunocompetent and immunocompromised hosts $(14,59$, 63). Although generally considered to be an infection with low virulence, two previously healthy patients with $B$ henselae bacteremia had a relapsing course, with long term antibiotic therapy required to eradicate infection (63). In a case-control study of 10 patients with $B$ quintana bacteremia, homeless inner city people with chronic alcoholism were primarily affected (64).

$B$ henselae, $B$ quintana and, in one instance, $B$ elizabethae have been isolated from the blood of patients with endocarditis who presented with symptoms including fever, weight loss and malaise (65-71). The majority had extensive disease involving the aortic valve that appeared to develop over a subacute clinical course (65-71). In apparent culture negative endocarditis, the use of the lysis-centrifugation culture method, and blind subculture to chocolate agar at days 7 to 14 , should be considered to increase the yield of Bartonella species (68). Staining blood culture bottle contents with acridine orange and cocultivation of blood samples with endothelial cells have also been used to isolate the organism (64,71). Additional diagnostic strategies include bartonella serology and analysis of valve tissue with culture, pathology and PCR where available (65-71). Antimicrobial therapy varied considerably among cases, and with most patients undergoing valvular surgery, no conclusive recommendations can be made. However, combined use of bactericidal agents with good activity against Bartonella species is appropriate (65).

$B$ vinsoni $i$, the Canadian vole agent, is not known to cause human disease; however, endocarditis in a dog due to a novel subspecies of $B$ vinsonii has been identified (72).

\section{PATHOPHYSIOLOGY OF B HENSELAE INFECTION}

Histopathological manifestations of infection with $B$ henselae are remarkably diverse. What determines the development of the necrotizing granulomatous type of lesion with microabscesses typical of CSD compared with vascular proliferative lesions seen with BA or BP is not known (28). The degree to which the host is immunocompromised may be a significant factor (73).

An inhibitory effect of $B$ henselae on human polymorphonuclear cells in terms of oxidative metabolism, degranulation and chemotaxis has been demonstrated $(74,75)$. The organism could therefore be able to survive and reproduce within polymorphonuclear cells, suggesting a potential mechanism for the development of the granulomatous inflammation seen in CSD lesions $(74,75)$.

$B$ henselae also directly stimulates endothelial cell prolif- eration and migration in vitro. Both effects are necessary for angiogenesis, as is seen in BA, to occur $(73,76)$. The effect is not unique to this Bartonella species, as $B$ bacilliformis has angiogenic activity $(77,78)$, and some isolates of $B$ quintana stimulate proliferation, but not migration (76). The regression of BA lesions with antimicrobial therapy of $B$ henselae or $B$ quintana infection supports the laboratory evidence that angiogenesis is stimulated by the organisms (76).

The identification of an angiogenic factor elaborated by Bartonella species, as well as the regulation of the host response that dictates the development of granulomatous inflammation versus neovascularization continue to be the subjects of ongoing research $(73,75,76)$.

\section{DIAGNOSIS OF CSD}

Before the identification of $B$ henselae as the causative organism of CSD, the lack of diagnostic tests made the confirmation of a clinical diagnosis problematic.

Traditionally a clinical diagnosis was made if three of the following four criteria were met: history of animal contact (usually cat) with an abrasion, scratch or ocular lesion; a positive CSD skin test; negative results of laboratory studies for other causes of lymphadenopathy; and characteristic lymph node histopathology (2).

The CSD skin test, using antigen prepared from lymph node aspirates from confirmed cases of the disease, has been used in a similar fashion to the tuberculin skin test (2). However, the test can reflect past exposure and be falsely negative in the first two weeks of the illness. In addition, the lack of a standardized preparation and safety concerns have limited its use (79).

$B$ henselae is a fastidious organism and can be difficult to isolate. Culture of the organism is not routinely available. Recommendations have been made to inoculate the sample directly onto a fresh blood or chocolate agar plate and hold plates for as long as six weeks in a carbon dioxide-enriched environment (5). As discussed earlier, yield from blood culture can be optimized with lysis-centrifugation, blind subculture, staining with acridine orange before subculture and cocultivation with endothelial cell lines $(64,68,71)$. Histopathological findings of lymph nodes are consistent but not pathognomonic and characterized by granulomas, stellate abscesses and a nonspecific inflammatory infiltrate. Small curved Gram-negative bacilli appear with Brown-Hopps Gram stain and are shown by Warthin-Starry silver staining (26). The pathological appearance of involved liver, spleen and bone is similar $(29,47)$.

Serological tests developed for the diagnosis of $B$ henselae have proven both sensitive and specific $(4,15,80)$ and provide a valuable tool for the confirmation of the clinical diagnosis of CSD. Sensitivities of $83 \%$ to $88 \%$ and specificities of $94 \%$ to $98 \%$ have been reported for the IFA assay developed at the Centers for Disease Control and Prevention, Atlanta, Georgia $(4,15,80)$. General applicability of the IFA test was demonstrated in a survey of 600 samples from across the United States, where the sensitivity of the assay was $82 \%$ when a broad case definition of any cat contact plus regional lymphadenopathy was applied (79). A sensitivity of $95 \%$ was found when the 
strict criteria of a cat scratch, papule formation and regional lymphadenopathy were met. Patients were considered seropositive if a single titre was 1:64 or greater; however, positive titres were usually 1:512 or greater (79). Generally, single titres have been 1:512 or greater in case reports of culture, pathology or PCR-confirmed CSD, or a rise in titre has been demonstrated $(42,48,56,81)$. In Switzerland, all patients with CSD studied had a titre to Bartonella species of 1:512 or greater. Among controls, including household, as well as urban and rural populations in general, only a single household subject had a comparable antibody level (82). Of these controls $58 \%$ from the rural area and $26 \%$ of those living in an urban area had titres $1: 64$ or greater, compared with a $3.6 \%$ positivity of controls in a Connecticut population (15), suggesting awareness of seroprevalence is necessary to establish appropriate cut-off values for the serological test (82). The IFA test currently available has shown significant crossreactivity between $B$ henselae and $B$ quintana (79). While BA, BP and trench fever are caused by $B$ quintana, this organism has not been identified in specimens from patients with CSD by culture or PCR $(6,48,79)$. Interpretation of a positive IFA test for Bartonella species should therefore be made in the context of clinical presentation.

Although not available as a routine diagnostic test, PCR hybridization assays that detect and differentiate between $B$ henselae and $B$ quintana directly in clinical specimens have been developed $(48,83)$. Anderson et al $(6)$ developed a PCR dot blot assay using primers that amplify a 414 base pair fragment of DNA common to $B$ henselae and $B$ quintana; internal oligonucleotides were then used as hybridization probes to differentiate between the Bartonella species. Using PCR hybridization for bartonella DNA of 89 lymph node aspirates from CSD skin test-positive patients and 137 aspirates and biopsies from CSD suspects, $96 \%$ and $60 \%$ were positive, respectively (7). No samples had DNA from $A$ felis identified. The low numbers of positives in the suspect group implicate alternate causes of the lymphadenopathy. As is the case with other diseases caused by difficult or slow to grow organisms, PCR could have a significant impact on the management of regional lymphadenopathy and potential cases of atypical CSD.

In summary, the currently available IFA assay for bartonella can confirm the typical presentation of CSD and can be used to diagnose the newly recognized, unusual manifestations of the disease. Positive tests to Bartonella species should be interpreted with caution because the acuity of infection is not indicated and seropositivity could merely reflect past exposure. Seroconversion, a fourfold change in titre or a single serum titre of 1:512 or greater would be reasonable serological criteria to confirm acute infection in a clinical setting suggestive of CSD or other bartonella-related disease process. High sensitivity should limit the need for invasive procedures, such as a lymph node biopsy in patients not considered at risk for malignancy. When atypical CSD or infection in immunocompromised hosts is suspected, the availability of tissue and/or blood samples for optimal culture techniques, PCR where available, and histopathology would be valuable.

\section{THERAPEUTIC ISSUES}

The usefulness of antibiotic therapy has not been established in controlled clinical trials. Because the majority of patients with CSD are not seriously ill, and improvement and resolution of lymphadenopathy are seen with or without therapy, the use of antibiotics for typical CSD is not routinely justified. In vitro susceptibility tests have found $B$ henselae to be sensitive to macrolides, tetracyclines, rifampicin and thirdgeneration cephalosporins, with intermediate sensitivity to trimethoprim/sulfamethoxazole (TMP/SMX) and aminoglycosides. The organism is resistant to first-generation cephalosporins and fluoroquinolones $(5,84)$. Original isolates from Slater et al (14) were broadly sensitive, with one of five isolates resistant only to penicillin, ampicillin and vancomycin, and another resistant only to tetracycline. In vitro susceptibility testing, however, has not been predictive of reports of clinical response.

In a retrospective assessment of uncontrolled data, the proportion of patients showing a partial or complete response to seven to 14 days of therapy was as follows: rifampin $87 \%$; ciprofloxacin $84 \%$; parenteral gentamicin sulphate $73 \%$; and TMP/SMX 58\% (85). Several case reports noted improvement in fever, lymphadenopathy, hepatosplenic lesions and central nervous system disease in association with various antimicrobial agents. Two patients with hepatic CSD and one with regional lymphadenopathy responded within $48 \mathrm{~h}$ to gentamicin therapy (86). Reports also suggest improvement in children with CSD treated with TMP/SMX for seven days and in adults prescribed ciprofloxacin $(87,88)$. In a recent series patients primarily treated with erythromycin or doxycycline, with or without the addition of rifampin, for four to six weeks appeared to respond positively to therapy (42). Interestingly, the response to erythromycin and doxycycline is dramatic in patients with BA, BP and bacteremia due to $B$ henselae, with rapid disappearance of fever and skin lesions $(57,89)$. Surgical intervention remains indicated if malignancy is suspected, drainage of any suppurative lymph node is required or other infectious diagnoses are being considered.

\section{CONCLUSIONS}

$B$ henselae has been established as the causative agent of CSD. Exposure to kittens and kittens with fleas are the most striking epidemiologic risk factors for CSD. Currently, available serological tests can confirm the typical presentation of CSD and identify $B$ henselae as the cause of more atypical cases, such as fever of unknown origin, granulomatous hepatitis, encephalitis and osteomyelitis. Symptomatic management is appropriate for isolated lymphadenopathy in well individuals. Antibiotic therapy may be indicated for patients with more severe manifestations of CSD and immunocompromised hosts. While the available evidence suggests that macrolides, tetracyclines, rifampin, third-generation cephalosporins, gentamicin and TMP/SMX all may have benefit, the issue of antibiotic therapy will not be settled until data from controlled clinical trials are available.

Significant advances in the understanding of the etiology 
and epidemiology of CSD have been made in this decade. Many questions, however, remain regarding the mechanism of transmission, pathogenesis and the overlapping spectrum of CSD and other $B$ henselae infections. Further study, in particular of the epidemiology and therapy of CSD, is warranted. In addition, a better understanding of the pathogenesis of $B$ henselae-related disease will have important implications in immunocompetent and immunocompromised populations.

\section{REFERENCES}

1. Debré R, Lamy M, Jammet ML, Costil L, Mozziconacci P. La maladie des griffes de chat. Bull Mem Soc Med Hop Paris 1950;66:76-9.

2. Margileth AM. Cat scratch disease. Adv Pediatr Infect Dis 1993;8:1-21.

3. Carithers HA. Cat-scratch disease: Notes on its history. Am J Dis Child 1970;119:200-3.

4. Regnery RL, Olson JG, Perkins BA, Bibb W. Serological response to 'Rochalimaea henselae' antigen in suspected cat-scratch disease. Lancet 1992;339:1443-5.

5. Dolan MJ, Wong MT, Regnery RL, et al. Syndrome of Rochalimaea henselae adenitis suggesting cat scratch disease. Ann Intern Med 1993;118:331-6.

6. Anderson B, Sims K, Regnery R, et al. Detection of Rochalimaea henselae DNA in specimens from cat scratch disease patients by PCR. J Clin Microbiol 1994;32:942-8.

7. Bergmans AMC, Groothedde J, Schellekens JFP, van Embden JDA, Ossewaarde JM, Schouls LM. Etiology of cat scratch disease: Comparison of polymerase chain reaction detection of Bartonella (formerly Rochalimaea) and Afipia felis DNA with serology and skin tests. J Infect Dis 1995;171:916-23.

8. Brenner DJ, O'Connor SP, Winkler JJ, Stelgerwalt AG. Proposals to unify the genera Bartonella and Rochalimaea, with descriptions of Bartonella quintana comb nov, Bartonella vinsonii comb nov, Bartonella henselae comb nov, and Bartonella elizabethae comb nov, and to remove the family Bartonellaceae from the order Rickettsiales. Int J Syst Bacteriol 1993;43:777-86.

9. Wear DJ, Margileth AM, Hadfield TL, Fischer GW, Schlagel CJ, King FM. Cat scratch disease: A bacterial infection. Science 1983;221:1403-5.

10. English CK, Wear DJ, Margileth AM, Lissner CR, Walsh GP. Cat-scratch disease: Isolation and culture of the bacterial agent. JAMA 1988;259:1347-52.

11. Brenner DJ, Hollis DG, Moss CW, et al. Proposal of Afipia gen nov with Afipia felis sp nov (formerly the cat scratch bacillus), Afipia clevelandensis sp nov (formerly the Cleveland Clinic Foundation strain), Afipia broomeae sp nov, and three unnamed genospecies. J Clin Microbiol 1991;29:2450-60.

12. Stoler MH, Bonfiglio TA, Stengbigel RT, Pereira J. An atypical subcutaneous infection associated with acquired immune deficiency syndrome. Am J Clin Pathol 1983;80:714-8.

13. Relman DA, Loutit JS, Schmidt TM, Falkow S, Tompkins LS. The agent of bacillary angiomatosis: An approach to the identification of uncultured pathogens. N Engl J Med 1990;323:1573-80.

14. Slater LN, Welch DF, Hensel D, Coody DW. A newly recognized fastidious Gram-negative pathogen as a cause of fever and bacteremia. N Engl J Med 1990;323:1587-93.

15. Zangwill KM, Hamilton DH, Perkins BA, et al. Cat scratch disease in Connecticut. N Engl J Med 1993;329:8-13.

16. Anderson B, Kelly C, Threlkel R, Edwards K. Detection of Rochalimaea henselae in cat-scratch disease skin test antigens. J Infect Dis 1993;168:1034-6.

17. Perkins BA, Swaminathan B, Jackson LA, et al [letter;comment]. Case 221992-Pathogenesis of cat scratch disease. N Engl J Med 1992;327:1599-1600.

18. Regnery RL, Anderson BE, Clarridge JE III, Rodriguez-Barradas MC, Jones DC, Carr JH. Characterizations of a novel Rochalimaea species, $R$ henselae sp nov, isolated from blood of a febrile, human immunodeficiency virus-positive patient. J Clin Microbiol 1992;30:265-74.

19. Regnery R, Martin M, Olson J. Naturally occurring 'Rochalimaea henselae' infection in domestic cat. Lancet 1992;340:557-8. (Lett)

20. Chomel BB, Abbott RC, Kasten RW, et al. Bartonella henselae prevalence in domestic cats in California: Risk factors and association between bacteremia and antibody titers. J Clin Microbiol 1995;33:2445-50.

21. Fumarola D, Giuliani G, Pece S. Cat-scratch disease: Single or multiple causative microorganisms? Pediatr Infect Dis J 1995; 14:822-3.

22. Alkan S, Morgan MB, Sandin RL, Moscinski LC, Ross CW. Dual role for Afipla felis and Rochalimaea henselae in cat-scratch disease. Lancet 1995;345:385.

23. Jackson LA, Perkins BA, Wenger JD. Cat scratch disease in the United States: An analysis of three national databases. Am J Public Health 1993;83:1707-11.

24. Carithers HA. Cat-scratch disease. An overview based on a study of 1200 patients. Am J Dis Child 1985;139:1124-33.

25. Hamilton DH, Zangwill KM, Hadler JL, Carter ML. Cat-scratch disease-Connecticut, 1992-1993. J Infect Dis 1995;172:570-3.

26. Demers DM, Bass JW, Vincent JM, et al. Cat-scratch disease in Hawaii: Etiology and seroepidemiology. J Pediatr 1995;127:23-6.

27. Jameson P, Greene C, Regnery R, et al. Prevalence of Bartonella henselae antibodies in pet cats throughout the regions of North America. J Infect Dis 1995;172:1145-9.

28. Schwartzman WA. Infections due to rochalimaea: The expanding clinical spectrum. Clin Infect Dis 1992;15:893-902.

29. Delahoussaye PM, Osborne BM. Cat-scratch disease presenting as abdominal visceral granulomas. J Infect Dis 1990;161:71-8.

30. Golden SE. Hepatosplenic cat-scratch disease associated with elevated anti-Rochalimaea antibody titers. Pediatr Infect Dis J 1993;12:868-71.

31. Lenoir AA, Storch GA, DeSchryver-Kecskemeti K, et al. Granulomatous hepatitis associated with cat scratch disease. Lancet 1988;i:1132-6.

32. Rizkallah MF, Meyer L, Ayoub EM. Hepatic and splenic abscesses in cat scratch disease. Pediatr Infect Dis J 1988;7:191-5.

33. Dangman BC, Albanese BA, Kacica MA, Wallach MT. Cat scratch disease in two children presenting with fever of unknown origin: imaging features and association with a new causative agent, Rochalimaea henselae. Pediatrics 1995;95:767-71.

34. Tolan RW, Schibler KR, Galliani CA, Kleiman MB. Unusual systemic, pseudomalignant manifestations of cat-scratch disease in siblings. Pediatr Infect Dis J 1990;9:913-6.

35. Margileth AM, Wear DJ, English CK. Systemic cat scratch disease: Report of 23 cases with prolonged vs recurrent severe bacterial infection. J Infect Dis 1987;155:390-402.

36. Talenti E, Cesaro S, Scapinello A, Perale R, Zanesco L. Disseminated hepatic and splenic calcifications following cat-scratch disease. Pediatr Radiol 1994;24:342-3.

37. Malatack JJ, Altman HJ, Nard JA, Wiener ES, Urbach AH, McGregor RS. Cat-scratch disease without adenopathy. J Pediatr 1989;114:101-4

38. Lewis DW, Tucker SH. Central nervous system involvement in cat scratch disease. Pediatrics 1986;77:714-21.

39. Carithers HA, Margileth AM. Cat-scratch disease - Acute encephalopathy and other neurologic manifestations. Am J Dis Child 1991;145:98-101.

40. Noah DL, Bresee JS, Gorensek MJ. Cluster of five children with acute encephalopathy, associated with cat-scratch disease in South Florida. Pediatr Infect Dis J 1995;14:866-9.

41. Grossman M, Azimi PH. An encephalitis syndrome in a seven year old. Pediatr Infect Dis J 1995;14:550-5.

42. Wong MT, Dolan MJ, Lattuada CP, et al. Neuroretinitis, aseptic meningitis and lymphadenitis associated with Bartonella (Rochalimaea) henselae infection in immunocompetent patients and patients infected with human immundeficiency virus type 1 . Clin Infect Dis 1995;21:352-60.

43. McCrary B, Cockerham W, Pierce P. Neuroretinitis in cat-scratch disease associated with the macular star. Pediatr Infect Dis J 1994;13:838-9.

44. Ulrich GG, Wsecker NJ, Meister SJ, Peterson TJ, Hooper DG. Cat scratch disease associated with neuroretinitits in a 6 year old girl. Opthalmology 1992;99:246-9.

45. Abbasi S. Pulmonary manifestations of cat-scratch disease; a case report and review of the literature. Pediatr Infect Dis J 1995; 14:547-8. 
46. Caniza MA, Granger DL, Wilson KH, et al. Bartonella henselae: Etiology of pulmonary nodules in a patient with depressed cell-mediated immunity. Clin Infect Dis 1995;20:1505-11.

47. Muszynski MJ, Eppes S, Riley HD. Granulomatous osteolytic lesion of the skull associated with cat-scratch disease. Pediatr Infect Dis J 1987;6:199-201.

48. Waldvogel K, Regnery RL, Anderson BE, Caduff R, Caduff J, Nadal D. Disseminated cat-scratch disease: Detection of Rochalimaea henselae in affected tissue. Eur J Pediatr 1994;153:23-7.

49. Shanon ABZ, Marchessault J, McDonald P. Cat-scratch disease associated with vertebral osteolytic lesion. Pediatr Infect Dis J 1989;8:51-2.

50. Walterspiel JN, Nimityongskul P. Positive bone scan in cat-scratch disease. Pediatr Infect Dis J 1987;6:944-5.

51. Cohen-Abbo A, Cheatham S, Edwards K. Disseminated cat-scratch disease simulating neuroblastoma. Pediatr Infect Dis J 1992;11:1058-60.

52. Margileth AM. Dermatologic manifestations and update of cat scratch disease. Pediatr Dermatol 1988;5:1-9.

53. Hashkes PJ, Trabulsi A, Passo MH. Systemic cat-scratch disease presenting as leukocytoclastic vasculitis. Pediatr Infect Dis J 1996;15:93-5.

54. Daye S, McHenry J, Roscelli JD. Pruritic rash associated with cat scratch disease. Pediatrics 1988;81:559-61.

55. Greenbaum B, Nelson P, Marchildon M, Donaldson M. Hemolytic anemia and hepatosplenomegaly associated with cat-scratch fever. J Pediatr 1986;108:428-30.

56. Apalsch AM, Nour B, Jaffe R. Systemic cat-scratch disease in a pediatric liver transplant recipient and review of the literature. Pediatr Infect Dis J 1993;12:769-74.

57. Tappero JW, Mohle-Boetani J, Koehler JE, et al. The epidemiology of bacillary angiomatosis and bacillary peliosis. JAMA 1993:269:770-5

58. Koehler JE, Quinn FD, Berger TG, LeBoit PE, Tappero JW. Isolation of Rochalimaea species from cutaneous and osseous lesions of bacillary angiomatosis. N Engl J Med 1992;327:1625-31.

59. Welch DF, Picket DA, Slater LN, Steigerwalt AG, Brenner DJ Rochalimaea henselae sp nov, a cause of septicemia, bacillary angiomatosis, and parenchymal bacillary peliosis. J Clin Microbiol 1992;30:275-80.

60. Perkocha LA, Geaghan SM, Yen TS, et al. Clinical and pathological features of bacillary peliosis hepatis in association with human immunodeficiency virus infection. N Engl J Med 1990;323:1581-6.

61. Koehler JE, LeBoit PE, Egbert BM, Berge TG. Cutaneous vascular lesions and disseminated cat-scratch disease in patients with the acquired immunodeficiency syndrome (AIDS) and AIDS-related complex. Ann Intern Med 1988;109:449-55.

62. LeBoit PE, Beiger TG, Egbert BM, et al. Epitheliod hemangiomalike vascular proliferation in AIDS: Manifestation of cat scratch disease bacillus infection. Lancet 1988;i:960-3.

63. Lucey D, Dolan MJ, Moss CW, et al. Relapsing illness due to Rochalimaea henselae in immunocompetent hosts: Implication for therapy and new epidemiological associations. Clin Infect Dis 1992;14:683-8.

64. Spach DH, Kanter AS, Dougherty MJ, et al. Bartonella (Rochalimaea) quintana bacteremia in inner-city patients with chronic alcoholism. N Engl J Med 1995;332:424-8.

65. Daly JS, Worthington MG, Brenner DJ, et al. Rochalimaea elizabethae sp nov isolated from a patient with endocarditis. J Clin Microbiol 1993;1:872-81.

66. Hadfield TL, Warren R, Kass M, Brun E, Levy C. Endocarditis caused by Rochalimaea henselae. Hum Pathol 1993;24:1140-1.

67. Spach DH, Callis KP, Paauw DS, et al. Endocarditis caused by Rochalimaea quintana in a patient infected with human immunodeficiency virus. J Clin Microbiol 1993;31:692-4.
68. Spach DH, Kanter AS, Daniels NA, et al. Bartonella (Rochalimaea) species as a cause of apparent 'culture-negative' endocarditis. Clin Infect Dis 1995;20:1044-7.

69. Jalava J, Kotilainen P, Nikkari S, et al. Use of polymerase chain reaction and DNA sequencing for detection of Bartonella quintana in the aortic valve of a patient with culture-negative infective endocarditis. Clin Infect Dis 1995;21:891-6.

70. Holmes AH, Greenough TC, Balacy GJ, et al. Bartonella henselae endocarditis in an immunocompetent adult. Clin Infect Dis 1995;21:1004-7.

71. Drancourt M, Mainardi JL, Brouqui P, et al. Bartonella (Rochalimaea) quintana endocarditis in three homeless men. N Engl J Med 1995;332:419-23.

72. Breitschwerdt EB, Kordick DL, Malarkey DE, Keene B, Hadfield TL, Wilson K. Endocarditis in a dog due to infection with a novel Bartonella subspecies. J Clin Microbiol 1995;33:154-60.

73. Koehler JE. Bacillary angiomatosis: Investigation of the unusual interactions between rochalimaea bacilli and endothelial cells. J Lab Clin Med 1994;124:475-7.

74. Fumarola D, Pece S, Fumarulo R, et al. Downregulation of human polymorphonuclear cell activities exerted by microorganisms belonging to the $\alpha-2$ subgroup of proteobacteria (Afipia felis and Rochalimaea henselae). Immunopharmacol Immunotoxicol 1994;16:449-61.

75. Fumarola D, Giuliani G, Petruzzelli R, Partipilo MR, Pece S. Pathogenicity of cat-scratch disease bacilli. Pediatr Infect Dis J 1994;13:162-3.

76. Conley T, Slater L, Hamilton K. Rochalimaea species stimulate human endothelial cell proliferation and migration in vitro. J Lab Clin Med 1994;124:521-8.

77. Garcia FU, Wojta J, Broadley KN, Davidson JM, Hoover RL. Bartonella bacilliformis stimulates endothelial cells in vitro and is angiogenic in vivo. Am J Pathol 1990;136:1125-35.

78. Garcia FU, Wojta J, Hoover RL. Interactions between live Bartonella bacilliformis and endothelial cells. J Infect Dis 1992;165:1138-41.

79. Dalton MJ, Robinson LE, Cooper J, Regnery RL, Olson JG, Childs JE. Use of bartonella antigens for serologic diagnosis of cat-scratch disease at a national referral center. Arch Intern Med 1995;155:1670-6.

80. Szelc-Kelly CM, Goral S, Perez-Perez GI, Perkins BA, Regnery RL, Edwards KM. Serologic responses to bartonella and afipia antigens in patients with cat scratch disease. Pediatrics 1995;96:1137-42.

81. Koranyi K. Fever, back pain and pleural effusion in a four-year-old boy. Pediatr Infect Dis J 1994;13:657.

82. Nadal D, Zbinden R. Serology to Bartonella (Rochalimaea) henselae may replace traditional diagnostic criteria for cat-scratch disease. Eur J Pediatr 1995;154:906-8.

83. Goral S, Anderson B, Hager C, Edwards KM. Detection of Rochalimaea henselae DNA by polymerase chain reaction from suppurative nodes of children with cat-scratch disease. Pediatr Infect Dis J 1994;13:994-7.

84. Maurin M, Raoult D. Antimicrobial susceptibility of Rochalimaea quintana, $R$ vinsonii, and the newly recognized $R$ henselae. J Antimicrob Chemother 1993;32:587-94.

85. Margileth AM. Antibiotic therapy for cat-scratch disease; clinical study of therapeutic outcome in 268 patients and a review of the literature. Pediatr Infect Dis J 1992;11:474-8.

86. Bogue CW, Wise JD, Gray GF, Edwards KM. Antibiotic therapy for cat scratch disease? JAMA $1989 ; 262: 813-6$

87. Collio PJ. Cat scratch disease: Therapy with trimethoprimsulfamethoxazole. Am J Dis Child 1992;146:397-9.

88. Holley HP. Successful treatment of cat-scratch disease with ciprofloxacin. JAMA 1991;265:1563-5.

89. Adal KA, Cockerell CJ, Petri WA. Cat scratch disease, bacillary angiomatosis, and other infections due to rochalimaea. $\mathrm{N}$ Engl J Med 1994;330:1509-15. 


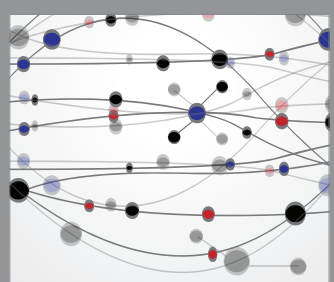

The Scientific World Journal
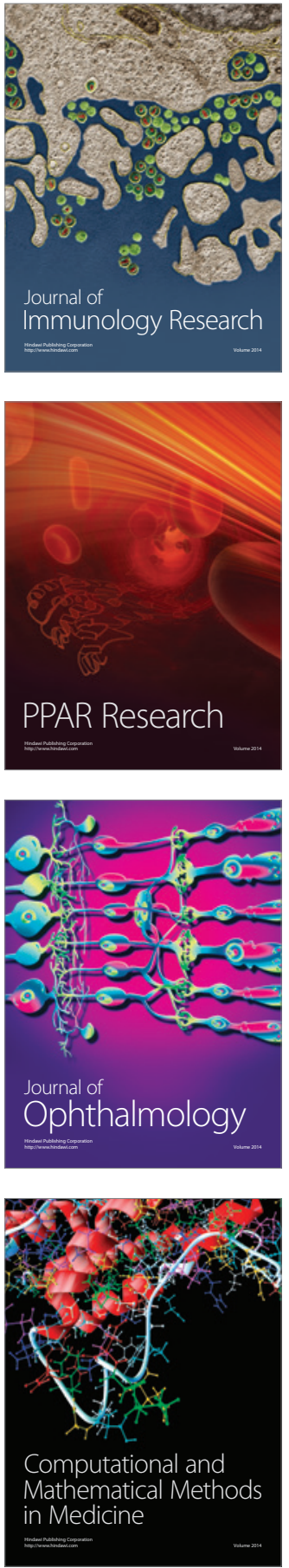

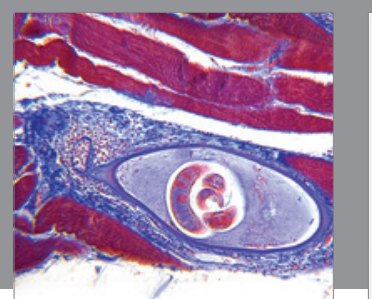

Gastroenterology Research and Practice

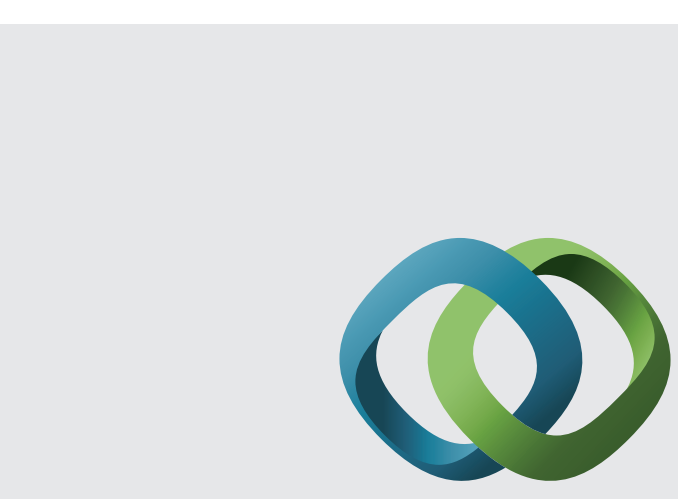

\section{Hindawi}

Submit your manuscripts at

http://www.hindawi.com
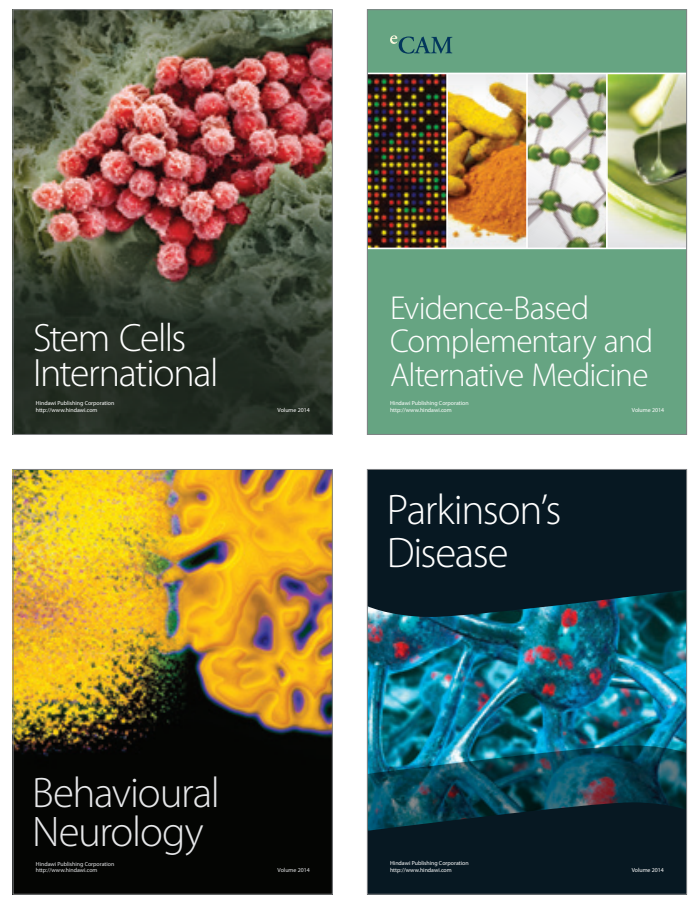
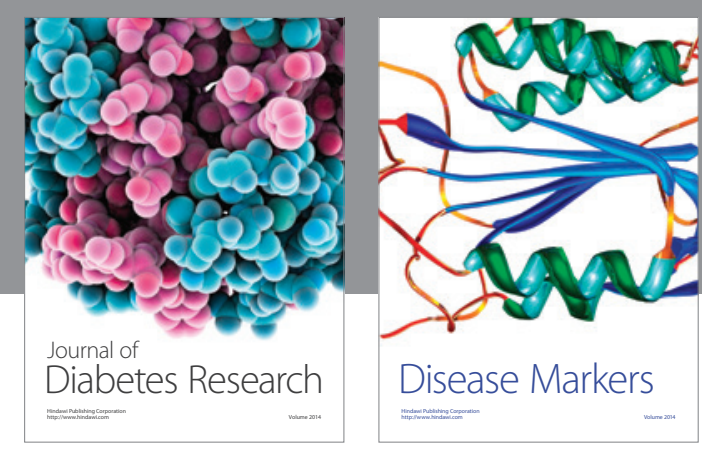

Disease Markers
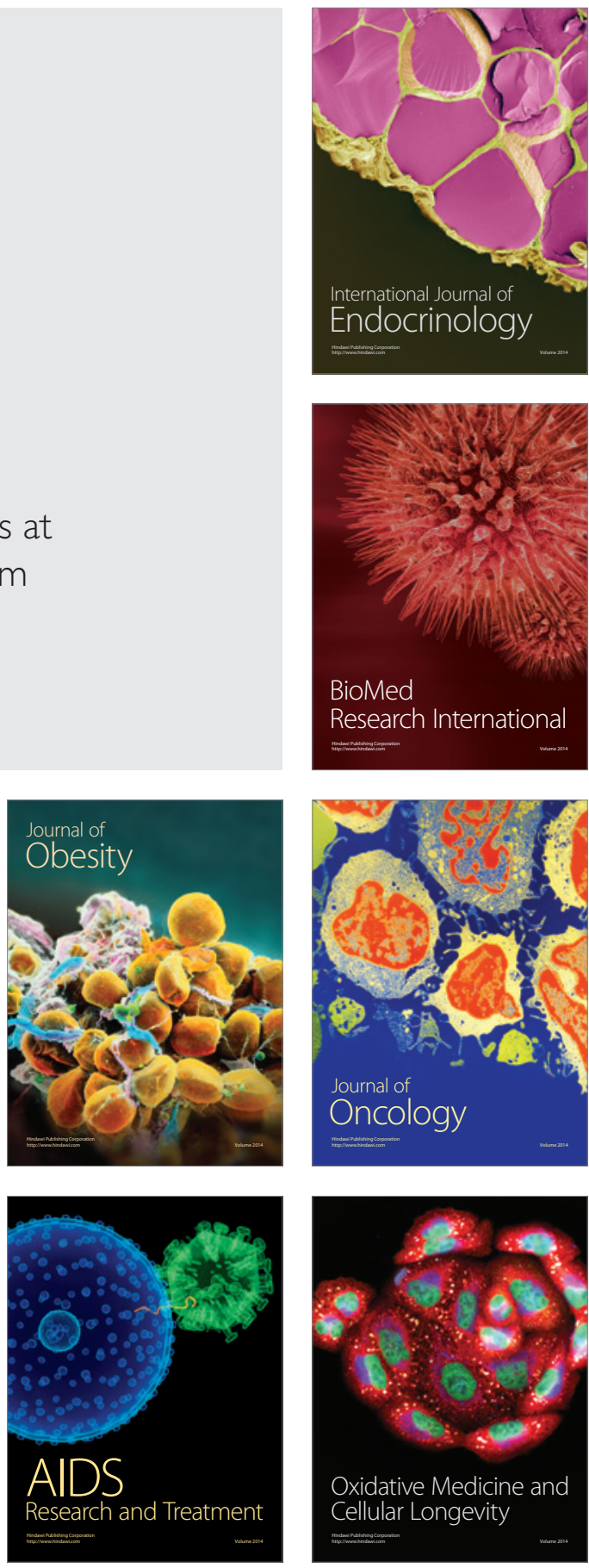